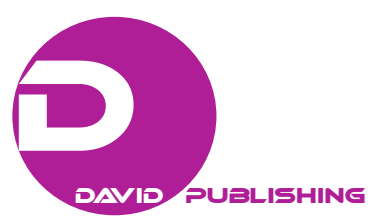

\title{
Values, Strengths, and Reality: A Multidimensional Reading of the Obama Phenomenon*
}

\author{
SHEN Wen-hui \\ Hunan Institute of Engineering, Xiangtan, China
}

\begin{abstract}
After fierce competition, Obama won the presidential race and was successfully elected as the first African-American President in US history. Unlike his predecessors, his success is primarily dependent on personal struggle rather than renowned family background or remarkable personal political experience and accomplishments; the change in US political environment reflected by the case is defined as "The Obama Phenomenon”. The Obama Phenomenon is the product of a variety of factors: The values of Individualism along with the philosophy of Pragmatism have built the macro-environment for it; Obama's elite political background and his excellent personal strengths have laid the foundation for his success; the mistakes in domestic and foreign affairs made by the Bush Administration made the Republican Party lose popular support, which removed the obstacles to Obama's success. This paper is to explore the reasons for Obama's success so as to contribute to a better understanding of the changes in US society, in particular its political environment, excavate the impetus for the changes, and rationally predict its tendency.
\end{abstract}

Keywords: The Obama Phenomenon, individualism, pragmatism, personal strengths, anti-terrorism, the Iraqi War, Subprime Crisis

\section{Introduction}

With the alternation of US president, a variety of changes will take place in US domestic politics along with its diplomacy, which will not only directly affect the real life of US citizens, but the economy and social life of other states as well, therefore, presidential election, as a big event in US political life, is also a world big event. In November 2008, Barack Obama, the Democratic candidate defeated its Republican rival John McCain and became the master of the White House. Given that Obama is the first African-American president in the US history and that his success does not depend on a prominent family background, the change in US political environment reflected by this case has come to be defined as "the Obama Phenomenon". When Obama was newly elected president, US was at the apogee of crises-the Subprime Crisis was worsening and the US economy was in danger, therefore the US citizens had higher expectations of him, and by virtue of his being the first African-American president, many people, in particular the African-Americans as well as Africans were

\footnotetext{
* Acknowledgements: The paper is initially a working one presented at ASN annual conference Wuxi in 2009, thanks go to the experts of the US diplomacy panel of the conference.

SHEN Wen-hui, Ph.D., Associate Professor of International Politics, School of Foreign Languages, Hunan Institute of Engineering.
} 
substantially inspired, which attracted a variety of scholars to strive to explore the reasons for Obama's success. This paper attempts to probe into "the Obama Phenomenon" from the perspectives of the US values, living philosophy, political environment, and Obama's overall strengths not forgetting his team in the purpose of warranting a thorough examination of the changes in US society along with its impetus.

\section{Individualism, Pragmatism and the Color Issue of Presidential Candidates}

The crucial point to win the presidential election is the support of electorates in the United States. As is clear to us, $70 \%$ of the total US population are Caucasians and the former 43 presidents are all white, Barack Obama, as an African-American, wants to become president, the first barrier will be whether or not the electorates can acknowledge his color, which is the basis of the support from electorates. Just as Obama himself has realized, he had to make them accept his color in order to make the electorates accept his idea of change (Thomas, 2009).

To judge whether electorates can accept Obama's color or not, a thorough analysis of the US values is required because it helps the public to form their standard for president candidates. Individualism is the core of American values (WANG, 1999). It is composed of two aspects: The first one is individual freedom. As the rational kernel of individualism, it attaches importance to people's value, advocates people's dignity, and lays stress on individual self-development; the second one is that everybody is created equal, that is, regarding interpersonal relationship, everybody is equal in reason.

First of all, the formation of individualism in the United States is closely related to the unshakable belief of "everybody is equal" in the mind of the early immigrants to "the New Continent". From the Mayflower Compact, the Declaration of Independence to the Constitution of the United States and the Civil rights Acts, the philosophy of "everybody is created equal” has been manifested repeatedly although not so clearly. What must be clarified is that "equal" hereon signifies that everybody is equal before opportunity and law rather than conditions and results. For this reason, the Americans adore civil freedom along with individual success, and the success should be achieved on the basis of individual struggle instead of ethnic feature, family background and other privileges. Thereout, a shared living attitude has formed — the American Dream: Everybody seizes the opportunities in their own new continent to strive for development, and never ceases to struggle for their success with their industriousness (WANG, 1999).

Second, the formation and evolution of the American values of individualism can not be separated from the structure of the early immigrants. Most of the early immigrants to North America were those of the middle or even lower class in their native countries, after arriving in North America, they gradually came to know that this was a completely new continent where there were no Kings and Lords, no cast system as that in Europe and even there were not any governance institutions - it is the wonderland of freedom they had dreamed of for a long time. Most of the initial immigrants to America were British Puritans who fled to the continent because of religious persecution. Due to their painful experiences in their native countries, they were much more persistent in the pursuit of religious freedom when compared with other immigrants. It is because they had experienced the incomparable real pain of religious torture that they could be able to maintain the utmost tolerance toward the later immigrants with different religious believes whatever their skin color is. Based on this point, the first group of immigrants had attempted to construct a democratic political system according to the political philosophies of Charles Louis Montesquieu, Voltaire, and Jean-Jacques Rousseau. Just as a Chinese scholar said, “The source of 
US diverse democracy can be tracked back to the religious tolerance during the period of colonism” (LI \& ZHOU, 1994, p. 5). Given this, although the US Constitution in 1787, to a certain degree, has reflected the British political traditions, however, it has also embodied the diversification in area, economic interest, religious belief, and culture (WANG, 1999).

Even so, the early plural democracy and political tolerance of the United States did not give birth to a fair society where everybody is equal. What have been accompanying the growing up of the States are the European immigrants' expelling the aborigines and depriving them of their rights, their discrimination against the African immigrants and racial segregation, and their exclusion of the Asian and Latin American immigrants. Ethnic conflicts including those between the peoples of different color, different races, and immigrant groups from different continents have been the major part of US social contradictions. In identity, for the early immigrants, the United States was mostly a geographical concept and later it turned into a nation one, however, in their self-awareness or subconsciousness, they had different identities- "What is my race (refers to color) and from which continent I come?” (WANG, 1999), which constitutes the reason that the Americans possess such a thorough understanding of their roots.

Of course, on the level of law, the situation has been improved substantially with the development of US civil rights movement. At the beginning of its founding, most of the black immigrants were compelled to work, and for a long time they had lived in the bottom of the society. Considering the unequal situation, George Washington, the founding father of the States, once argued, "There is not a man living who wishes more sincerely than I do, to see a plan adopted for the abolition of slavery” (Washington, 1786). With the ablution of the Civil War, the 13th Amendment to the U.S. Constitution was approved in 1865, which prescribes, "Neither slavery nor involuntary servitude, except as a punishment for crime whereof the party shall have been duly convicted, shall exist within the United States, or any place subject to their jurisdiction” (LI, 1999, p. 791). And then, the 15th Amendment to the Constitution was ratified in 1870, which grants African-American men the right to vote by declaring that the "right of citizens of the United States to vote shall not be denied or abridged by the United States or by any state on account of race, color, or previous condition of servitude” (LI, 1999, p. 792). Nevertheless, on the level of real life, the blacks and colored people were still deprived of their political rights by white people, and the situation was not effectively improved until 1960s. In the first half of 1960s, a new Civil Rights Act and the Voting Rights Act were passed by the Congress, the former one legally prohibits discrimination based on race, color, religion, sex, and national origin by federal and state governments as well as some public places, and the latter one prohibits any jurisdiction from implementing a "voting qualification or prerequisite to voting, or standard, practice, or procedure... in a manner which results in a denial or abridgement of the right... to vote on account of race, color, or language minority status" (See Section $4 \& 5$ of the Transcript of Voting Rights Act (1965)). With the development of legislation in civil rights, the political condition of blacks and colored people has been improved greatly, and since then a variety of ethnic minorities set to participate in government and political affairs. In 1984 and 1988, black politician Jessie Jackson ran for president two times, although he failed in them, his courage, determination, and perseverance have triggered the enthusiasm of blacks' for participating in politics and gradually the American society has extensively acknowledged their participation. As a matter of fact, when the electorates choose their administrators, color does not constitute the crucial point for their consideration nowadays, which is the major reason that there emerged some black figures in US cabinets 
such as Colin Powell, Condoleezza Rice and so forth.

Pragmatism is Americans' living philosophy, and it can be taken as the derivative of their values. The key aspect of the Americans' national characteristics is “laying emphasis on practical results”, namely, they believe in and practice the philosophy of pragmatism in their social life. They argue, "If philosophy denied the innuendoes of experience, the philosophy—not experience—must be rejected” (Boorstin, 1958, p. 152), which signifies, without the fetter of old philosophy, typical American philosophy is one kind of pragmatic philosophy, it focuses on experience rather than speculation. There is no wonder that, as early as 1930s, French historian Alexis de Tocqueville once commented, "I think that in no country in the civilized world is there less interest in philosophy than in the United States” (Nolla, 2010, p. 698).

The formation of pragmatic philosophy in the United States is closely connected to its character of an immigrant nation. The purposes for the early European immigrants trudging to North America can be divided into three categories: The first one is those in pursuit of religious salvation, that is, they intended to find an ideal place to enjoy religious freedom and be free from religious persecution; the second one is those in the pursuit of political outlet, namely, they desired to seek for political freedom to avoid despotic rule; the third one is those in the pursuit of material wealth, which means, while they kept their soul and body together, they could realize their dream to make a fortune (DENG, 2001). Despite the immigrants possessed different religious believes, came from different continents, and belonged to different races, they shared common philosophy of freedom and equality, therefore a diverse, democratic, and tolerant society was constructed, where the two seemly contradictory aspects - religious belief and pursuit of material wealth coexisted harmoniously. At the beginning of founding the thirteen colonies, according to the doctrine of Protestantism, the immigrants shaped the norms of mundane behavior composed of seemly contradictory elements such industriousness and thriftiness, continence, and enterprising along with solemn life attitude. However,

When the limitation of consumption is combined with this release of acquisitive activity, the inevitable practical result is obvious: accumulation of capital through ascetic compulsion to save. The restraints which were imposed upon the consumption of wealth naturally served to increase it by making possible the productive investment of capital. (Webber, 1930, p. 90)

Hence those seemly contradictory elements have formed a harmonious unity. At the same time, Puritans held that to build a "Realistic Paradise" depended on the fortune coming from hardworking rather than a pure heart and few desires resulted from superfluous and hackneyed religious rites and practices. Based on these ideas, a strong sense of utility and practicability derived from the social practice of conquering nature and exploiting the frontier and it became the organic ingredient of US Protestantism. In this case, the religious moral norms were infused with mundane entrepreneurial spirit, which signifies that success from personal struggle is regarded as the symbol of soul salvation, and hence the old idea of equating fortune with evil has been wiped out, which is the origin of the US pragmatic philosophy (WANG, 1999).

With the guide of individualism and pragmatism, the American people have formulated their standard for presidential candidates: native-born American having religious belief, possessing the quality of industriousness, honesty and team spirit, and owning the capability to safeguard and realizing the US national interests; regarding to color, it is unnecessarily the crucial factor for their consideration.

Based on this standard, what the electorates care about contains two points. The first point is that whether the 
presidential candidate is the embracer as well as defender of the mainstream culture or not, just as some researchers pointed out, the barrier does not lie in color, cultural belief is fundamental (WANG, 1999). Although Obama is not one of the members of the American mainstream society-White Anglo- Saxon Protestant (WASP), however, he is by no means a rebel of WASP values, and he has not intention to shake the superiority complex of white. Conversely, Obama has turned himself into the representative of the American mainstream values as well as the enhancer of the superiority complex of white because Obama is a native-born American. He received higher education in US first-class university, and he has been lived with the influence of the American mainstream values. Therefore, he is more like the model of American national assimilation than the symbol of national fusion. Given these reasons, Obama's color exercises slight influence on the support and recognition from white. On contrary, his color brings him plenty of advantages because he is an African-American, he can win not only the support of his own race, but that of other electorates with different colors and native origins, such as the Asian Americans and Latin Americans. According to the authoritative statistics, only 56\% of the qualified black electorates participated in the polling of the general election in 2004, while the percentage surged to $70 \%$ in 2008 , which was the first time for the percentage of the participants to exceed $10 \%$ of the electorates, most of whom were young people and non-white electorates, precisely, there was a black and a Hispanic American in five participants (WANG, 2009). Meanwhile the Asian Americans in particular the Chinese Americans, who usually take no much interest in politics, have actively voted in the election and the number is much bigger than that of any previous general elections, and most of them voted for Obama. The second one is whether or not he/she owns the capability to govern their country well, safeguard their safety, better their well-being, and lead their nation to go farther on the road of global hegemony. People may still remember the situation when George Bush and Bill Clinton competed against each other for presidency. Due to the victory in the Gulf War, George Bush was respected by the populace as a national hero and thus acquired a high support rate, which was as high as $82 \%$ in March 1991. But unfortunately due to the long-term economic recession, the slowly recovering economy did not bring the populace tangible benefits. Therefore George Bush’s support rate dropped to as low as 39\% in April 1992 (TAO, 2004, p. 230). In view of the situation, Bill Clinton played the economy card and finally won the campaign. This is the best manifestation of the American pragmatic philosophy as well as their pragmatic living attitude.

Based on the above analysis, it can be concluded that the United States is a country whose social life is dominated by individualism and pragmatism, and with centuries of struggle for civil rights and the development of social civilization, racism has gradually waned and took the place of "the American Dream", which focuses on "Everybody is equal before law and opportunity and success can be achieved only through self-help”, has been widely accepted and practiced. Therefore, for Obama, color is not to constitute an insurmountable barrier to his campaign success.

\section{Personal Strengths, the Democratic Nomination, and the Campaign Team}

That Obama's color does not constitute the key barrier means that he will likely win the support from the root grass rather than that he will certainly win the campaign, because, according to the procedure of presidential election, there are two barriers that he has to break through, one of which is the nomination of the Democratic Party. 
To win the Democratic nomination, Obama has to defeat his inner party rival—the former US first lady, Hilary Clinton. Whether he can succeed or not in it, to a large extent, relies on the resources available to him. According to the tradition of US general election, the amount of resources is determined by family background as well as political background.

On the surface, Obama is at disadvantage compared with Hilary Clinton in these two aspects. Obama was born in an ordinary family, before he decided to participate in the competition, he was just a congressman, which signifies his connections with other politicians are neither wide nor intimate, and his foundation in political arena is not so firm either. Therefore the political resources and financial resources Obama is accessible to are quite limited. Furthermore, as a low ranking politician, he is easily attacked by his rival with the excuse of inexperience.

While for Hilary Clinton, the situation is quite different. Though she was not born in a prominent family, she and her husband have built their political popularity and accumulated sufficient political capital. In 1992, Bill Clinton defeated his Republican rival and successfully captured the White House. With the eight-year elaboration, President Clinton has built wide, close, and strong connections with other American politicians. As Clinton's wife, Hilary accessible to all the resources his husband possesses. It is due to this point that Hilary can easily win the support of her peers let alone raise sufficient funds for her campaign. Given that, some experts commented, the whole nation is at the back of Hilary (Thomas, 2009). With regard to personal political background, Hilary is honored as a well-informed, widely acknowledged, and fairly competent legislator, and therefore in the Senate, she is more influential than Obama (Thomas, 2009).

Compared to Hilary, Obama has been the federal congressman for only three years. For this reason, Hilary intended to play the experience card in the purpose of defeating Obama. However things always go contrary to people's wishes, from the electorates' point of view, there is no doubt that experience is important, but to be experienced or not is not absolute. Furthermore, any administration is a leading collective, which, rather than only president, is composed of President, vice-President, Secretary of State, Secretary of Defense, Chairman of the Joint Chiefs of Staff and so forth. What is more, from his political career, Obama has gathered plenty of experience: He once served as the president of the most influential law journal—-the Harvard Law Review shortly after his graduation from Harvard University, and then he entered political circle by joining Illinois state congress. During his career as a state congressman, he offered services to the public as a community organizer and lawyer. He was successfully elected as the federal congressman in 2005, and worked in the U.S. Senate Committee on Health, Education, Labor, and Pensions, supervising the planning of healthcare, education, employment, and retirement. Meanwhile, he was one of the members of the U.S. Senate Committee on Foreign Affairs, where he came into contact with foreign affairs and participated in the making of foreign policies. Soon afterwards, he worked in the U.S. senate Committee on Environment and Public Affairs, taking charge of supervising environmental protection and funding highway construction. During his political career, he gradually formed his unique political personality and principle — caring for the people. As early as he was an Illinois state congressman, he worked with other lawmakers from both the Democratic Party and the Republican Party and passed the bill of "Making work pay" in order to improve the life standard of the working families, which reduced receipt tax by as much as 100 million US dollars. Obama's caring for the people style reflected from this case has formed a distinct comparison with Hilary's arrogant image (Duodu, 2008). At the same time, in the competition with Obama, 
Hilary played race card, committed personal politics, which resulted in the loss of her political resources. While Obama was more tactful, as he attempted to keep himself off the entangling political controversy as well as the parochial vested interest groups, which left Hilary in the dust. Therefore, while Obama obtained the support from his Democratic peers, he also won the support from the elites of both parties such as the Kennedy family, Republican politician Colin Powell, and even Hollywood, who had been supporting Hilary, turned to back Obama by offering a huge amount of contribution (Thomas, 2009). It was due to Obama's personal strengths and charisma that he successfully won the nomination of the Democratic Party.

For Obama, winning the nomination of the Democratic Party is the basic but important step of the road to the White House, however, if he intends to win the race to the White House, he has to defeat another powerful rival-the Republican presidential candidate. The history of US presidential campaign indicates that an excellent campaign team and appropriate campaign strategies are undoubtedly of top importance to win the race. Therefore, what must be added are Obama's campaign team and their strategies along with their implementation, as they can also prove Obama's personal strengths.

Based on the understanding of US campaign tradition, Obama made great efforts to establish an exceptionally powerful and capable campaign team, it was composed of a variety of elites: Jon Favreau-the "pen” of the former Democratic presidential candidate, John Kerry, the Chief strategist David Axelrod, who is skillful in playing the grass-root card, media officer Robert Gibbs, and certainly Obama’s wife Michelle Obama. Apart from this point, Obama selected an appropriate campaign partner-the senior white congressman Joe Biden. Nowadays, although nobody will openly declare them to be a racist, the indisputable fact is that there still exists the consciousness of racism in American society. Under such circumstances, it is a wise strategy for Obama to select Joe Biden as his campaign partner, namely, vice-president of his administration established after winning the campaign. Joe Biden, the 65-year old senator, was chairman of the U.S. Senate Committee on Foreign Relations at that time, as a senior statesman, he was elected as a senator at the age of 30, and was once the youngest senator in his time. Due to his long-term political career, Biden owns a deep understanding of international affairs and enjoys a good fame in the arena of foreign affairs. Choosing Biden as the campaign partner can be called "killing two birds with one stone”. First of all, Biden can effectively make up Obama's inexperience in diplomacy, which can not only prevent his Republican rival from making an issue of his inexperience in foreign affairs, but give the public more confidence in the prospective Obama administration. Secondly, it can effectively dispel the possible worries of white that Obama is the betrayer of American mainstream culture and therefore, from the perspective of race, eliminate the psychological unbalance of white - the state is in the hands of blacks. The American mainstream culture is that of WASP, namely, the religious values of White Anglo-Saxon Protestants. If Obama had selected another black or a colored as his campaign partner, it would have certainly given birth to a misconception: Blacks led by Obama are plotting to seize power from white and will implement new racialism after his taking office, which is the taboo for Obama's success because white occupies $70 \%$ of the total population in America, without whose support, Obama absolutely has no means of winning the campaign.

Furthermore, American politics is a typical money politics, just as a saying in American political arena goes, "Money is the mother's milk of politics" (ZHANG, 2002). One of the most important indications is that sufficient fund is the basis for any politician to win elections, especially the presidential campaign. The reason for such a 
tremendous expenditure for presidential campaign is that the candidate has to build up their campaign team, utilize all kinds of means and channels to extensively publicize their political ideas and governing philosophy, attend all kinds of rallies, all of which will cost a good deal of funds. The amount of funds raised relies on two factors: the degree of the electorates' support and the capability of the campaign team. According to the American election law, the funds for presidential campaign can be raised from individuals as well as non-governmental businesses and organizations. It is estimated that the campaign expense in 2008 was as high as USD2.4 billion, which set a historical high. In this campaign, Obama successfully raised USD620 million, which hit the highest in the history of US presidential campaign, and was much more than that done by his Republican rival McCain (ZHANG, 2009). The success for his fundraising is made up of three reasons. First, Obama's correct political ideas have won the support of electorates. In the process of the campaign, Obama unequivocally expounded his solutions to the issues citizens cared about. Regarding the Iraqi War, he proposed a 16-month timetable for the withdrawal of US forces from Iraq. In terms of economy, he designed some specific measures to create job opportunities and alleviate the burden of labors. For instance, he suggested to pass the Windfall Profit Tax Bill so as to finance each family with USD1,000 of emergency energy cost and proposed a USD50 billion economic stimulus plan to prevent one million labors from losing their jobs (Obama, 2009). On this account, Obama's campaign funds mostly came from the grass root, though the contribution from each one was not big, the number of the donor was remarkably big. The second is the bidirectional communication between Obama and the electorates. Previously presidential candidates generally conducted top-down and unidirectional communication with citizens, but this time Obama reformed the conventional approach and engaged two-way and equal exchange with the electorates, hence he achieved unexpected effects: He harvested 3.1 million of donators, 5 million of volunteers, 2.2 million of supporters on the Internet, and the sum of supporters reached 7 million (Fineman, 2008). Lastly, Obama made full use of new media means. Realizing the benefits brought about by advanced information technology, Obama's team has designed their website and built their Internet as well as mobile fundraising platforms, in this way, it is more convenient for electorates to make their donations. The use of new media brought them great success, according to their statistics, $85 \%$ of their funds were donated through the Internet (WANG, 2009). Thanks to sufficient funds, Obama's campaign entered a virtuous cycle because he could utilize the leading mass media to propagandize his political ideas more actively and finally he became the focus of mass media, in return, he won not only more donations but more votes as well.

To sum up, because Obama is not from a glamorous political family and does not possess outstanding political background, the resources he can be accessible to are limited, when compared with his inner party rival, Hilary Clinton. However, with his powerful personal strengths, he organized a united team, designed and implemented a variety of wise strategies, and finally successfully overcame his disadvantages, which contributed to his winning the Democratic nomination and laid a firm foundation for him to defeat the Republican rival.

\section{The Bush Administration's Policy Mistakes, the Republican Candidate's Failure and Obama's Success $^{1}$}

US politics is typical bipartisan politics, it means the Democratic Party and the Republican Party take turns

\footnotetext{
${ }^{1}$ The Bush Administration in this paper refers to that of George W. Bush.
} 
in power and in their competition the winner takes all. Therefore the last and the crucial barrier to Obama's success is from the outside of the Democratic Party, that is, the Republican Party. It is easy to understand that if the Republican administration had effectively dealt with the international affairs in such a rapidly changing world and developed its economy and improved the citizens' well-being, it would have maintained a high support rate. Under such circumstance, there would be little possibility for the Democratic Party to win the campaign; however, the reality is quite different.

What human being pursue are no more than three aspects: peaceful living environment; affluent material life; religious freedom and social fairness (WANG, 1999), which, to a certain extent, are similar to the "Four Freedoms” advocated by former US president Franklin Roosevelt: freedom of speech and expression, freedom to worship God, freedom from want and freedom from fear. In these aspects, there is no exception to American citizens. But compared with the elites of other states, the American elites have more appeals: Whether the US supremacy can be maintained or consolidated. This sentiment is originated from their religious belief —Protestantism. Protestantism stemming from Calvinism during the colonial period has molded the American mainstream culture as well as ideology, the core of whose doctrines is "Chosen People" and "Manifest Destiny". According to this logic, the American people regard themselves as the most excellent "Chosen People", and take their nation as the Redeemer of other nations, and intend to spread the Gospel to the whole world. Therefore, both the commons and the elites possess one kind of inherent sense of mission in their minds, they argue that US shoulders the responsibility to enforce the justice on behalf of Heaven. "Justice” herein refers to the doctrines of Christianity, American democracy, market economy, civil liberty, and man's natural rights. Based on this perception, their expectation for the government imperceptibly contains the maintaining of US world leadership. Naturally, for the elites, their expectation is mingled with the realization of different kinds of interests because the existence of interest groups is also one of the outstanding characteristics of US political life and they play a key role in shaping as well as implementing US foreign policies.

However, the lackluster achievements made by the Bush administration in domestic as well as foreign affairs not only depressed the commons but dissatisfied the elites as well.

First of all, regarding national security, with the deepening of anti-terrorism campaign, US did not successfully eradicate the threats from terrorism and hence the citizens still lacked the sense of safety. After the “9/11 Event”, dramatic change took place to US security environment: known as the world only superpower, US security is universally acknowledged to be impregnable, however, by hijacking civil airplanes, a few terrorists affiliated with Al-Qaeda effortlessly destroyed the World Trade Center and stormed the Pentagon. Since then, terrorism has turned into the primary threat to US national security. Although the Bush administration had crushed Taliban regime, and pulled down Saddam Hussein by military means, but it made a series of mistakes. The first one is that in counterterrorism approach. The birth of terrorism owns miscellaneous causes including economic, political, cultural, and religious one, hence, in order to eradicate the root of terrorism, multiple means rather than the sole military approach are required. Nevertheless, the Bush administration excessively worshipped military force, just as one old Chinese saying goes, the result is "using anti-craft guns to kill mosquitoes, missing the point”. The second mistake is wrong counterterrorism philosophy. Shortly after the “9/11 Event”, George W. Bush immediately defined the fight against terrorism as a war. As terrorists mainly came from the Islamic world, inadvertently his administration turned the fight against terrorism into the war 
between the US-led Christian civilization and the Islam civilization, which had verified Huntington's theory of "the Clash of Civilizations". The wrong policy toward terrorism led to a variety of negative effects: At home, the American muslins were extremely dissatisfied with the Republican Party; at abroad, anti-America sentiment from the Muslin world continuously swelled. The third mistake lies in the anti-terrorism center. The terrorist organization plotting and implementing the attack to US is Al-Qaeda, which is headquartered in Afghanistan and sheltered by Taliban regime, Afghanistan is naturally the focus for US anti-terrorism campaign. But after smashing Taliban, the Bush administration shifted its course and attacked Iraq with fictitious reasons, ${ }^{2}$ the consequence is that although Saddam Hussein was toppled, Iraq, just like Afghan, was plunged into endless turbulence, and in order to consolidate the military victory US had to deploy a huge number of forces and thus was mired in both Afghanistan and Iraq. Due to the policy mistakes of the Bush administration, for a long period of time, the head of Al-Qaeda, Bin Laden seemed to have evaporated from the earth, the danger of a Talibanized Afghanistan was persistently incremental, and terrorist attacks targeting US objectives within and outside its borders did not abated either. US entered a vicious cycle: The more US fights against terrorism, the more it faces terrorist attacks and the worse its security is. Under this situation, the US government had to strain its nerve all the time in an effort to safeguard its national security. In this case, citizens did not obtain security as they initially expected, what is worse is that huge amount of military expenditure has led to a stretched national finance, which is to undermine their social welfare.

Second, concerning the maintaining of US global hegemony, the Bush administration has weakened its hard power and soft power. In terms of comprehensive national power, with the collapse of the Soviet Union, US is undoubtedly the only super power in the current world, it possesses the capability and the responsibility to lead the world, which is the consensus of the whole nation. However, the populace and the Republican government have different points of view on how to maintain its global leadership and how to lead the world. Joseph S. Nye Jr. once pointed out,

Not since Rome has one nation loomed so large above others. In the words of The Economist, "the United States bestrides the globe like a colossus. It dominates business, commerce and communications; its economy is the world's most successful, its military might second to none”. (Nye, 2002, p. 1)

However, such powerful strength does not mean, without the cooperation of other nations, US can settle all the problems it is encountered. He warned,

Globalization - the growth of networks of worldwide interdependence-is putting new items on our national and international agenda whether we like it or not. Many of these issues we cannot resolve by ourselves. International financial stability is vital to the prosperity of Americans, but we need the cooperation of others to ensure it. Global climate change, too, will affect American's quality of life, but we cannot manage the problem alone. And in a world borders are becoming more porous than ever to everything from drugs to infectious diseases to terrorism, we are forced to work with other countries behind their borders and inside ours. (Nye, 2002, pp. XIII-XIV)

Therefore, he argued, "We are not only bound to lead, but bound to cooperate" (Nye, 2002, p. XIV). According to Joseph Nye, unilateralism will undermine US national interests, only multilateralism can be the flexible approach to preserve US supremacy. Unfortunately, under the guide of neo-conservatism, the Bush

\footnotetext{
2 In 2003, US launched a war against Iraq under the pretext of Saddam Hussein's preserving WMD and violating the related UN resolution No.1441, but through strict inspection by UN experts, such weapons were not found.
} 
administration went to extremes, it made a fetish of US military and economic power, and went to unilateralism. On international relations front, it took some actions in quick procession leading to a dramatic decline in the key bilateral and multilateral relations between US and other powers or power group. At the beginning of George W. Bush's taking office, his government positioned China as US strategic competitor, and strengthened its containment to China, which resulted in a substantial decline in Sino-US relations. ${ }^{3}$ Meanwhile, it had also tightened its containment to Russia, which worsened the US-Russian relationship to a historical freezing point. Furthermore, by ignoring the opposition from France and Germany and bypassing the UN, it unilaterally launched a war against Iraq, which produced a big rift in the US-Atlantic alliance and further worsened the tense relations between US and other permanent members of the UN Security Council. In international obligations, firstly, on the one hand, as one of the key contracting states of ABM (Treaty on the Limitation of Anti-Ballistic Missile Systems), it obstinately withdrew from the treaty. Such action set a malicious example in damaging the current WMD (Weapon of Mass Destruction) nonproliferation regime. On the other hand, it threatened to launch preemptive attack to the so-called "Rogue States" and "Axis of Evil”, who attempt to seek WMD and are connected to terrorism, and the initiative had not only aroused hatred from some small nations such as North Korea, Iran, Syria and so on, but triggered worries of some big powers such as China and Russia and therefore, they sped up their nuclear development or improved their nuclear arsenal so as to cope with the possible threat from US.

Secondly, while other nations was actively bearing their obligations in combating climate change, the Bush administration turned a blind eye to the reality of global warming, refused to approved the Kyoto Protocol, which signifies that, as the de facto world leader, US intentionally shirked the international obligations it ought to undertake for the purpose of safeguarding its narrow national interests. ${ }^{4}$ All in all, during the two terms of George W. Bush's, his administration had deviated from US diplomatic tradition—taking a middle way between idealism and realism. Although the neoconservatives left the administration later on, the consequences of their policy could not be erased immediately: US strength was severely weakened and its international prestige dramatically declined and hence its leeway on the world stage substantially shrank. The mistakes revealed that the policies of the Bush administration did not comply with both the US moral norms and its national interests. It is no wonder that Joseph S. Nye once commented that the citizens expected the government to treasure the fruits of the Cold War and carry them forward; however, instead of consolidating US global hegemony, the Bush administration wasted its hard power and undermined its international prestige (Nye, 2002).

Thirdly, in domestic affairs, the Bush administration has also made a series of mistakes, the crucial one lies in the poor regulation of the financial institutions, which led to the eruption of financial crisis. General speaking,

\footnotetext{
${ }^{3}$ On April 1, 2001, a Chinese fighter jet collided with a US spy plane in the South China Sea, leading to a serious diplomatic dispute and thus the bilateral relations was severely damaged, with the outbreak of " $9 / 11$ Event", the relations was pulled back to normal track the next year.

${ }^{4}$ The Kyoto Protocol was passed in December 1997, the signing started in March 1998, and took effect in 2005. As an international law, the aim is to reduce the emission of greenhouse gases so as to protect mankind from the harms resulted from global warming and extreme weather. It requires all the UN members, especially the biggest producer of greenhouse gases such as USA, China, and India and the western industrialized countries undertake their responsibilities to reduce the emission of greenhouse gases USA signed the agreement in 1998, but in 2001, the Bush Administration refused to approve it with the excuse of "Reducing the emission of greenhouse gases will harm US economy and developing countries should shoulder the same responsibilities as USA”.
} 
the commons pay little attention to politics, especially foreign affairs, only if their state is secure, because they hold that politics is the business of elites. But when it comes to economy, they have quite different attitudes, as it is closely connected to their well-being, therefore the public, to some extent, can stand up the mistakes in foreign affairs made by the government, when their consequence is not fatal, but for those in economy, in particular big mistakes, they have no way to keep silence, as they will harm their living quality. Even though the subprime crisis starting at the second half of 2007 did not entirely expose when the campaign started, the citizens had felt that "the rising wind forebodes the coming storm", their houses along with jobs were teetering on the brink of losing. Just as people worried about, the crisis eventually evolved into the global financial crisis in the second year, which led to severe downturn of the US economy and the world economy. Although Obama designed and implemented a plenty of bailouts to save economy later on, there is no denying that the crisis has severely affected people's well-being, from which it can be seen how poor legacy the Bush Administration has left to his successor.

In terms of the political achievements of the Bush administration, no indicator is as persuasive as public opinion. In October 2008, public opinion in US indicated: $47 \%$ of the respondents held that the political achievements of the Bush administration were quite poor; $66 \%$ of them argued that the nation was going in wrong direction, with the evolution of the financial crisis, the percentage rose to as high as $79 \%$ (Carville, 2008). Due to the poor performance, the support rate of George W. Bush was much lower than that of his predecessors such as Richard Nixon and Jimmy Carter, and he was granted the name of "the worst president".

By this token, the Republican Party has lost its soul, and the economic crisis has shaken electorate's confidence in it (Baker, 2008). Under this situation, John McCain is driven into a dilemma: (1) As the Republican presidential candidate, he has to defend the Bush administration for its domestic and foreign policies, otherwise, he will lose the basis for his identity of the Republican candidate. (2) He is clear that there are few shining points for the performance of the Bush Administration in the past eight years, and his party has lost people's hearts and minds therefore change is fatally required, which makes it necessary that McCain has to distinguish himself from George W. Bush. Nevertheless, no matter what efforts McCain spares, it is impossible for him to achieve such a goal. For instance, regarding the Iraqi War, McCain maintains to support it and keep defending the government for its operation; however, the public insist that the war has caused severe consequences such as squandering the nation's financial resources, causing an unnecessary burden to the nation, and creating fresh dangers for national security. Apart from this point, the Iraqi War owns moral significance, as it can be used as the "touchstone" to test people's honesty and their respect for life because the war has been proved to be a wrong one launched with a fabricated reason; therefore McCain's supporting the war is equal to supporting the Bush administration to lie. Meanwhile, the war has caused the loss of thousands of innocent lives, which brings the victims' families permanent and indelible pain. A wrong war which causes the loss of lives, in a nation of Viva La Vida, is desecration of life. While to be honest and respect life are the key elements of US ethics and morals, and they are the benchmarks to measure the moral level of politicians, which means a politician who is not honest and does not respect life by no means win the trust of others, let alone the support of electorates.

Therefore, no matter how hard the Republican candidate McCain tries to save his party, his efforts would be in vain, and no matter how his team operates, they are doomed to be defeated. Therefore, it is the Bush administration that ruined the political future of the Republican Party as well as its presidential candidate. Seeing from this point, Obama's success is natural, rational, and logical. 


\section{Conclusion}

An ancient Chinese sage, Mencius once said, “Good timing isn’t as important as advantageous geographic terrain; but advantageous geographic terrain isn’t as important as harmonious inter-personal relations” (天时不 如地利，地利不如人和, Tian Shi Bu Ru Di Li, Di Li Bu Ru Ren He). It refers to that, to win a war, good timing, advantageous geographical terrain, and harmonious inter-personal relations are all indispensible, of them, harmonious inter-personal relations, which means the support of the public, is the vital factor.

If we attempt to explore the connotations of the above wisdom today, it can be inferred that people's success depends on some necessary subjective and objective conditions. According to the above analysis, Obama's success originated from a variety of factors: First, the US values have shaped the standard for the public to choose their president, that is, to what extent, they can improve people's life standard and lead US to go farther on the road of world hegemony, which constitutes the macro-environment as well as the major objective factor for Obama’s success, namely, “Good timing” (天时,Tian Shi); second, the mistakes in external and internal affairs made by the Republican administration have ruined the future of its presidential candidate therefore only if Obama wins the nomination of the Democratic Party, actually he will not have any rival ahead, which is the realistic condition for Obama's success, that is, “Advantageous geographic terrain” (地利, Di Li); lastly, Obama's powerful personal strengths has contributed to the construction of a solidary campaign team, the raise of reasonable administrative program and the design and implementation of appropriate strategies and campaign techniques, all these factors have greatly contributed to winning extensive support of the electorates, which constitutes another vital condition for his success, that is, “Harmonious human relations” (人和, Ren He). Therefore, by no means, is Obama's success fortuitous.

The Obama Phenomenon is the vivid portrayal of the current US society: In a country adoring individualism, everybody can likely achieve their goal through determination, integrity, and hardworking; the characteristics of a immigrant nation and its cultural diversification have given birth to a tolerant civil society, which in return has strengthened the idea of "everybody is equal”; just as the pragmatic tradition handed down by their ancestors, material interests remain one of the key considerations for citizens to select their leader. Therefore, the Obama Phenomenon has proved that the US values of individualism, pragmatic living philosophy, and moral standard will maintain unchanged because they are the essence of the American culture; however, with time going by, the US society is to become more open, tolerate, and diversified.

\section{References}

Baker, G. ( October 31, 2008). American isn't about to become liberal heaven. Financial Times. Boorstin, D. (1958). The Americans; the colonial experience. New York: Random House. Carville, J. ( October 30, 2008). Blame the party, not the campaign. Financial Times.

Complete Collection of United States Statutes at Large. Retrieved August 1, 2015 from http://www.constitution.org/uslaw/sal/sal.htm

DENG, S. S. (2001). 世代悲欢“美国梦”一美国移民的历程及种族矛盾 (1607-2000) (Joys and sorrows of the American

Dream - the process of the US immigration and its racial contradictions). Beijing: China Social Sciences Publishing House. Duodu, C. (2008). The Obama phenomenon. New African, 471, 72-75.

Fineman, H. (October 25, 2008). What have we created?! Newsweek. 
Transcript of voting rights act. (1965). Retrieved September $30, \quad 2015 \quad$ from http://www.ourdocuments.gov/doc.php?flash=true\&doc=100\&page=transcript or https://www.law.cornell.edu/uscode/text/52/10301

Li, D. K. (1999). The American government and the American politics. Beijing: The Commercial Press.

LI, Q. Y., \& ZHOU, Y. G. (1994). 美国现代化道路 (The American modernization road). Beijing: People’s Publishing House.

Nolla, E. (Ed.). (2010). Democracy in America. (J. T. Schleifer, Trans.). Indianapolis, Indiana: Liberty Fund Inc.

Nye, S. J. Jr. (2002). The paradox of American power: Why the world only superpower can't go it alone. Cambridge: Oxford University.

Obama, B. (2009). Change we can believe in. Manhattan, NY: Three Rivers Press.

TAO, W. Z. (2004). 中美关系史 (1972-2000) (下卷) (The history of Sino-US relations (1972-2000) (Volume II)). Shanghai: Shanghai People's Publishing House.

Thomas, E. (2009). A long time coming. Philadelphia, PA: Public Affairs.

WANG, J. S. (1999). 高处不胜寒一冷战后美国的全球战略和世界地位 (Lonely at the top一The US global strategy and world leadership after the Cold War). Beijing: World Affairs Press.

WANG, L. M. (2009). 浅析奥巴马总统选举获胜的原因 (An analysis of Obama’s success in the presidential campaign). Law \& Society, (3), 221.

Washington, G. (April 12, 1786). The Papers of George Washington: The Confederation Series (Vol. 4) (University of Virginia). Retrieved August 1, 2015 from http://gwpapers.virginia.edu/

Webber, M. (1930). The Protestant ethic and the spirit of capitalism. London \& Boston: Unwin Hyman.

ZHANG, L. P. (2002). 美国政党与选举政治 (The US political parties and election politics). Beijing: China Social Sciences Publishing House.

ZHANG, Z. Y. (2009). 奥巴马大选获胜的原因及政治影响 (An analysis of the reasons for Obama’s victory in the general election and its political influences). International Information, (11), 42-44. 